\title{
HUBUNGAN SENSORY PROFILE DENGAN KEMANDIRIAN AKTIFITAS FUNGSIONAL DAN PRESTASI AKADEMIK ANAK SEKOLAH DASAR (SD) KELAS SATU DI DESA SAWAHAN, NGEMPLAK, BOYOLALI
}

\author{
Lis Sarwi Hastuti, Rina Kurnia \\ Kementerian Kesehatan Politeknik Kesehatan Surakarta Jurusan Okupasi Terapi
}

\begin{abstract}
Sensory Profile, Independence Of Functional Activity, Academic Achievement. This study aims to determine whether there is a relationship between the level of sensory profile with independence of functional activity and academic achievement of Primary School-aged children in Sawahan Village, Ngemplak, Boyolali.This study uses an analytical study design with cross sectional correlation. Sampling collection was done by quota sampling technique against first grade in four primary schools in Sawahan village, Ngemplak, Boyolali.The result of Pearson product moment correlation was obtained $p$ value $=0.000$ and $(r)=0.880$ for the variable sensory profile - independence, while variable sensory profile - academic achievement obtained $p$ value $=0.029$ and $(r)=0.345$. Conclusions results of this research is there a relationship between the sensory profile of the independence and academic achievement of first grade Primary School-aged children in the Sawahan village, Ngemplak District, Boyolali. It shows the higher score obtained by children in SSP (child closer to typical performance or is at normal level) either higher the score of independence of the child (the child more independent) and academic achievement is getting better and otherwise.
\end{abstract}

Keywords : Sensory Profile, Independence Of Functional Activity, Academic Achievement

\begin{abstract}
Abstrak : Sensory Profile, Kemandirian Aktifitas Fungsional, Prestasi Akademik. Penelitian ini bertujuan untuk mengetahui hubungan antara sensory profile dengan kemandirian aktifitas fungsional dan prestasi akademik anak kelas satu SD di Desa Sawahan, Ngemplak, Boyolali. Desain penelitian ini adalah analitik korelasi dengan pendekatan cross sectional. Pengambilan sampel dilakukan dengan teknik quota sampling terhadap anak kelas satu di empat SD Desa Sawahan, Ngemplak, Boyolali. Hasil uji korelasi pearson product moment diperoleh $p$ value $=0,000$ dan $(\mathrm{r})=0,880$ untuk variabel sensory profile - kemandirian, sedangkan variabel sensory profile prestasi akademik diperoleh $p$ value $=0,029$ dan $(\mathrm{r})=0,345$. Kesimpulan Hasil penelitian ini adalah ada hubungan antara sensori profile dengan kemandirian dan prestasi akademik anak kelas satu Sekolah Dasar di Desa Sawahan, Kecamatan Ngemplak, Kabupaten Boyolali. Hal ini menunjukkan semakin tinggi skor SSP yang diperoleh oleh anak (anak semakin mendekati typical performance atau berada pada tingkat normal) maka skor kemandirian anak semakin tinggi (anak semakin mandiri) dan prestasi akademiknya semakin baik dan sebaliknya.
\end{abstract}

Kata Kunci : Sensory Profile, Kemandirian Aktifitas Fungsional, Prestasi Akademik 


\section{PENDAHULUAN}

Masa kanak-kanak merupakan masa pertumbuhan dan pembelajaran yang pesat. Anak-anak kelas satu (disebut Grade 1 di beberapa negara) adalah anak yang berada di kelas pertama Sekolah Dasar setelah TK dengan rentang usia biasanya 6 sampai 7 tahun (The national curriculum, 2014). Pengalaman yang diperoleh seorang anak pada masa ini memiliki dampak yang besar terhadap perkembangannya di masa depan. Anak mengandalkan indera pengelihatan (visual), taste (gustatory), sentuhan (taktil), pendengaran (auditory), bau (penciuman), proprioception (umpan balik dari otot dan sendi) dan vestibular (keseimbangan) untuk belajar dan menafsirkan lingkungannya, hal ini dikenal dengan pemrosesan sensori, dan pertumbuhan dari indera yang dimiliki oleh anak dikenal sebagai perkembangan sensorik (Schaaf, et al., 2010). Penelitian menunjukkan perkembangan sensorik dimulai sejak saat kehamilan dan waktu yang penting untuk perkembangan sensorik adalah antara usia 5 dan 8 tahun. Dalam hal ini setiap individu termasuk anak-anak memiliki pattern yang berbedabeda untuk setiap sensori (Krantz, 2009).

Sensory processing disorders (SPD) mempengaruhi 5\% - $16 \%$ dari anak-anak dan dapat menyebabkan kerusakan jangka panjang perkembangan intelektual dan sosial (Ahn et al. , 2004, Ben- Sasson et al. , 2009a, Brett -Green et al. , 2008 dan Bundy et al. , 2007). BenSasson et al. (2009) memaparkan bahwa 1 dari 6 anak mengalami sensory symptoms yang secara signifikan mempengaruhi aspek-aspek dari everyday life functions anak.

Kemampuan fungsional atau kemandirian dapat didefinisikan sebagai kemampuan seseorang untuk terlibat dalam tindakan yang berarti berhubungan dengan pekerjaan, bermain dan tugas hidup sehari-hari, dalam konteks yang relevan, sedangkan prestasi akademik didefinisikan sebagai capaian tingkat keberhasilan tentang suatu tujuan karena usaha belajar yang dilakukan oleh seseorang secara optimal (Fisher, 2003), Parham dan Mailloux (2005) menyebutkan bahwa masalah pemrosesan sensori sering dikaitkan dengan penurunan keterampilan sosial, keterampilan bermain, gangguan konsep diri, penurunan keterampilan motorik halus dan kasar dan kesulitan melakukan aktivitas keseharian.

Ketika anak-anak menunjukkan perilaku yang terkait dengan disfungsi integrasi sensorik, maka akan terdapat hipotesis bahwa mereka menghadapi pengalaman sensorik dari lingkungan anak melalui sistem otak yang tidak teratur atau terbatas dalam kemampuannya untuk memproses dan mengintegrasikan informasi sensorik (Bundy \& Murray, 2002). Oleh karena itu anak-anak dengan defisit pengelolaan sensorik mungkin mengalami kesulitan saat terlibat dalam tugas-tugas sekolah, bermain, ADL, kesadaran dari personal inefficacy, kurangnya kontrol, atau ketidakpuasan dengan kinerja mereka (Mulligan, 1996). Berdasarkan pemaparan tersebut, penulis tertarik untuk mengetahui lebih mendalam dan melakukan penelitian mengenai keterkaitan antara sensory profile dengan kemandirian aktifitas fungsional dan prestasi akademik anak kelas satu Sekolah Dasar.

\section{METODE PENELITIAN}

Desain penelitian yang digunakan adalah analitik korelasi dengan 
pendekatan cross sectional. Arikunto (2006) menyatakan bahwa penelitian korelasi bertujuan untuk mengetahui sejauh mana hubungan antara variabel yang diteliti.

Rancangan cross sectional merupakan rancangan penelitian yang pengukuran atau pengamatanya dilakukan secara simultan pada satu saat atau sekali waktu (Hidayat, 2007). Metode analitik korelasi digunakan untuk mengukur hubungan antara sensori profile dengan kemandirian dan prestasi akademik anak kelas I (satu) Sekolah Dasar.

\section{HASIL PENELITIAN}

Sebelum menentukan teknik analisis data statistik, dilakukan uji normalitas data. Uji normalitas data digunakan untuk mengetahui apakah populasi data berdistribusi normal atau tidak. Dalam penelitian ini, dilakukan uji normalitas Kolmogorov-Smirnov dengan derajat kesalahan $\alpha$ 0,05 (5\%) melalui program Statistical Product and Service Solution (SPSS) for Windows 22. Kriteria yang digunakan untuk mengetahui normal tidaknya sebaran data adalah jika $\mathrm{p}>0,05$ maka sebaran data dinyatakan normal. Namun, jika $p<0,05$, maka sebaran data dinyatakan tidak normal. Untuk lebih jelasnya, dapat dilihat pada tabel di bawah ini.

\section{Tabel 1}

Uji Normalitas Kolmogorov-Smirnov Data Responden

\begin{tabular}{lllll}
\hline \multicolumn{1}{c}{$\begin{array}{c}\text { Jenis } \\
\text { Pengukuran }\end{array}$} & \multicolumn{1}{c}{$\mathrm{p}$} & \multicolumn{1}{c}{$\alpha$} & $\begin{array}{c}\text { Kriteri } \\
\mathrm{a}\end{array}$ & Keterangan \\
\hline Sensori & 0,27 & 0,0 & 0,278 & berdistribu \\
profile & 8 & 5 & $>0,05$ & si normal \\
Kemandiria & 0,05 & 0,0 & 0,053 & berdistribu \\
n & 3 & 5 & $>0,05$ & si normal \\
Prestasi & 0,54 & 0,0 & 0,546 & berdistribu \\
akademik & 6 & 5 & $>0,05$ & si normal \\
\hline
\end{tabular}

Berdasarkan tabel 1, dapat dilihat bahwa uji normalitas KolmogorovSmirnov untuk semua data berdistribusi normal ( $p>0,05)$ (Dahlan, 2011).

Uji analisis data yang akan digunakan adalah uji parametris teknik analisis korelasi bivariat dengan koefisien korelasi Pearson Product Moment dengan derajat kesalahan $\alpha 0,05(95 \%)$. Kriteria yang digunakan untuk uji hipotesis dalam penelitian ini adalah jika $\mathrm{p}<\alpha$ maka $\mathrm{Ha}$ diterima, yaitu terdapat hubungan antara sensory profile dengan kemandirian dan prestasi akademik anak kelas satu Sekolah Dasar. Berikut adalah tabel analisis uji hipotesis korelasi bivariat dengan koefisien korelasi Pearson Product Moment dalam penelitian ini.

Tabel 2

Korelasi Bivariat Pearson Product Moment Sensori profile dengan Kemandirian dan prestasi akademik

\begin{tabular}{|c|c|c|}
\hline Jenis Pengukuran & $\mathrm{p}$ & $\bar{A}$ \\
\hline $\begin{array}{l}\text { Sensori } \\
\text { kemandirian }\end{array}$ profile- & 0,000 & 0,05 \\
\hline $\begin{array}{l}\text { Sensori profile- } \\
\text { prestasi akademik }\end{array}$ & 0,029 & 0,05 \\
\hline
\end{tabular}

Dari tabel 2, menggunakan teknik korelasi bivariat koefisien Pearson Product Moment derajat kesalahan $\alpha 0,05$ (95\%) diperoleh nilai $\mathrm{p}<0,05$, sehingga dapat dinyatakan bahwa terdapat hubungan antara sensori profile dengan kemandirian dan prestasi akademik anak kelas satu Sekolah Dasar.

Tabel 3

Kekuatan Korelasi Bivariat Pearson Product Moment

\begin{tabular}{lc}
\hline \multicolumn{1}{c}{ Variabel } & $\mathrm{R}$ \\
\hline Sensori profile-kemandirian & 0,880 \\
Sensori profile-prestasi akademik & 0,345 \\
\hline
\end{tabular}

Berdasarkan keterangan pada table 3, diperoleh koefisien korelasi variabel sensori profile - kemandirian (r) 0,880 
yang berarti hubungan antara sensori profile dengan kemandirian anak kelas satu Sekolah Dasar berada pada hubungan yang erat (reliabel) dengan nilai positif berarti memiliki hubungan yang linear. Dengan demikian semakin tinggi skor sensori profile yang dicapai anak yaitu anak mendekati atau berada pada tingkat kemampuan sensori normal maka skor kemandirian anak akan semakin tinggi dan sebaliknya. Untuk variabel sensory profile - prestasi akademik diperoleh nilai (r) 0,345 yang berarti hubungan antara sensori profile dengan prestasi anak kelas satu Sekolah Dasar berada pada hubungan yang lemah dengan nilai positif berarti memiliki hubungan yang linear. Dengan demikian semakin tinggi skor sensori profile yang dicapai anak yaitu anak mendekati atau berada pada tingkat kemampuan sensori normal maka skor prestasi akademik anak akan semakin tinggi dan sebaliknya.

\section{PEMBAHASAN}

Hasil penelitian ini menunjukkan bahwa terdapat hubungan yang antara sensory profile dengan prestasi akademik anak kelas satu Sekolah Dasar. Hal ini dapat dibuktikan dari hasil uji statistik menggunakan uji parametris teknik analisis korelasi bivariat koefisien korelasi Pearson Product Moment menunjukkan nilai $\mathrm{p}=0,029(\mathrm{p}<0,05)$ dan hasil koefisien korelasi (r) 0,345 , nilai positif pada hasil koefisien korelasi (r) berarti hubungan antara sensory profile dengan kemandirian anak kelas satu Sekolah Dasar memiliki hubungan yang lemah dan linear.

Beberapa penelitian yang sejalan dengan hasil penelitian ini antara lain Ashburner et al. (2008) yang menyimpulkan bahwa anak-anak yang mengalami gangguan pemrosesan sensori prestasi akademiknya lebih rendah. Padankati (2005) menuliskan bahwa anakanak dengan kesulitan belajar (learning disabilities) memiliki sensory profile yang berbeda dibandingkan anak-anakyang tidak memiliki kesulitan belajar. Polatajko et al. (1991) menyimpulkan bahwa pemberian intervensi sensori integrasi selama 9 bulan dapat meningkatkan capaian akademik (academic achievement).

Selain beberapa penelitian di atas, menurut Krantz (2009) menuliskan bahwa sistem sensori yang baik akan mempengaruhi perkembangan komponen yang lain dalam tubuh manusia, karena sistem sensori merupakan pondasi/dasar perkembangan komponen yang lain termasuk di dalamnya komponen akademik/prestasi akademik. Menurut Auer (2008) bahwa sensory perception berhubungan erat dengan rasionalisasi sehingga akan berpengaruh pada modalitas belajar, misalnya observasi empiris dan mencari sebab akibat dari suatu kejadian.

\section{KESIMPULAN DAN SARAN}

Berdasarkan hasil uji korelasi pearson product moment diperoleh $p$ value $=0,000$ dan $(r)=0,880$ untuk variabel sensory profile - kemandirian, sedangkan variabel sensory profile prestasi akademik diperoleh $\mathrm{p}$ value $=$ 0,029 dan $(r)=0,345$.

Hasil ini menunjukkan ada hubungan antara sensori profile dengan kemandirian dan prestasi akademik anak kelas satu Sekolah Dasar di Desa Sawahan, Kecamatan Ngemplak, Kabupaten Boyolali. Hal ini menunjukkan semakin tinggi skor SSP yang diperoleh oleh anak (anak semakin mendekati 
typical performance atau berada pada tingkat normal) maka skor kemandirian anak semakin tinggi (anak semakin mandiri) dan prestasi akademiknya semakin baik dan sebaliknya.

Saran untuk penelitian yang akan datang adalah peneliti diharapkan melakukan penelitian berbentuk tim dimana terdiri dari 2 orang atau lebih sehingga penelitian berjalan efektif dan efisien

\section{DAFTAR RUJUKAN}

Ahn, R.R., Miller, L.J., Milberger, S., \& McIntosh, D. (2004). Prevalence of parents' perceptions of sensory processing disorders among kindergarten children. American Journal of Occupational Therapy, 58, 287-293.

Arikunto, S. (2006). Prosedur penelitian suatu pendekatan praktik. Jakarta: Rineka Cipta.

Ashburner, J., Ziviani, J., Rodger, S. (2008). Sensory Processing and Classroom Emotional, Behavioral, and Educational Outcomes in Children With Autism Spectrum Disorder. American Journal of Occupational Therapy, Vol. 62, No. 5

Auer, M. (2008). Sensory Perception, Rationalism and Outdor Environmental Education. International Research in Geographical and Environmental Education, Vol. 17 no.1

Ayres, J.A. (1972). Sensory integration and learning disorders. Los Angeles, CA: Western Psychological Services.

Brett, B.A., Miller, L.J., Gavin, W.J., \& Davies, P.L. (2008). Multisensory integration in children: A preliminary ERP study. Brain Research, 1242, 283 - 290.

Bundy, A.C., Shia, S., Qi, L., \& Miller, L.J. (2007). How does sensory processing dysfunction affect play? American Journal of Occupational Therapy, 61, 201 208.

Fisher, A.G. (2003). The Assessment of Motor and Process Skills (5th ed., Vols. 1-2). Fort Collins, CO: Three Star Press.

Hidayat, A. (2007). Metode penelitian kebidanan dan teknik analisis data. Jakarta: Salemba Medika.

Krantz, J. (2009). Experiencing Sensation and Perception. Pearson Education. Canadian Journal of Occupational therapy, 75:220229.

Notoatmodjo, S. (2010). Metodologi penelitian kesehatan. Jakarta: PT Rineka Cipta.

Rockwood, K. (2007). The Measuring, meaning, and importance of activities of daily living (ADLs) as an outcome. International Psychogeriatrics 19, (3), 467-482.

Schaaf, R.C., Benevides, T., Blanche, E.I., Brett-Green, B.A., Burke, J.P., Cohn, E.S., Koomar, J., \& Schoen, S. (2010). Parasympathetic functions in children with Sensory processing disorder. Journal of Applied Psychology, 77, 336 342.

White, B., Mulligan, S., Wright. (2007). Sensori-motor, sensory processing deficits and daily living skills of children. American Journal of Occupational Therapy, 61, 190200. 